\title{
Factor identification in managerial ethics
}

\author{
C. A. Bisschoff and R. A. Lotriet* \\ Potchefstroom Business School, Potchefstroom Campus, North-West University, South Africa.
}

Accepted 28 September, 2012

\begin{abstract}
Business is expected to serve the common good of all stakeholders and have special legal interests with regard to upholding the values embedded in the constitution. Proper managerial ethics is becoming more of a concern within the context of business as the risks involved have grown in number, complexity, likelihood and significance. The extent of organisational pressure on management to perform accordingly on various indicators may also lead to compromises on organisational standards of ethical business conduct in order to achieve the bottom line and related objectives. The aim of this research is to measure the dimension of ethical attitudes amongst managers along a number of stated business scenarios which illustrate that managers may often be exposed to situations where they experience problems with role definition and other related interactions at their work place. The research used a questionnaire as measuring instrument to assess the attitudes pertaining to the ethical perceptions of managers. Data collection was implemented by administering the survey to a sample of managers with at least 2 years managerial experience. Six categories of factors were identified from the data analysis which are labelled as indirect ethical grey areas; devious behaviour; insider trading; leaking of competitive information; integrity and bribes.
\end{abstract}

Key words: Business ethics, morals, values, attitudes, decision making, management.

\section{INTRODUCTION}

Managerial behaviour in the markets is now more transparent than ever before with globalization opening up markets through advances in communications and rapid technological transfer that adds to the widening of the so-called "moral gap". Therefore, injustice anywhere is becoming more visible and less acceptable. Reaction to business recklessness, exploitation, dishonesty and negligence is also becoming increasingly more potent. There are now real incentives for doing the right things, and real disincentives for doing the wrong things, but concern over the recent increase of numerous misdeeds by management require a focus on the ethical dimensions which seems to be a complex dilemma for decision makers.

\section{Problem statement}

Ethics research have a traditionally strong focus on the

\footnotetext{
*Corresponding author. E-mail: ronnie.lotriet@nwu.ac.za.
}

philosophical foundations of business in a democratic society (Preble and Reichel, 1988). Contemporary studies have basically been using two complimentary approaches. The Conceptual approach have attempted to address the meaning of business ethics, moral conduct and social responsibility to assist management in making more ethical decisions. The Empirical approach focus on evaluating prevailing ethics, perceptions and attitudes of the various stakeholders - for example KPMG's regular surveys (IBE, 2010) concluded that most companies had recently experienced white-collar crime involving large amounts and that a significant proportion of perpetrators in South Africa were in management.

Lauer (2009: 1) refers to a division between the "doing of business" and the "doing of ethics", and an underestimation of ethical dilemmas that arise from conflicts of interest. Increasing unethical practices were thought to be caused by (IBE, 2010; Camerer, 1996) the weakening of society's values and business ethics in particular; economic pressures such as the prolonged recessions; political uncertainties and increasingly sophisticated crime networks exploiting information technology. These type of transgressions usually thrive in 
an environment characterised by low ethical standards and moral flexibility.

As a consequence, there seem to be a perceived deficit of values in business which creates the need for a rethinking of the underlying ethical norms (WEF, 2010: 5). The ultimate challenge to South African managers is the strengthening of the moral dimensions in the workplace (Shankar, 2010: 47). The need for this is evident through recent examples such as Escom whose executive committee negotiated an average of $83 \%$ pay hikes (Eybers, 2010: 1) versus the $8.5 \%$ annual increase which they were not prepared to pay the average worker. It is also allegated that the South African tender processes are not "objective, equitable and transparent"; and that the persons who evaluated the tenders were guilty of misconduct and/or corruption (Steinacker, 2010: 13). The ruling governing party has been linked to questionable funding sources including kickbacks from the R30bn arms deal and a R38,5bn subcontract linked to its investment vehicle, Chancellor House, for the supply of boilers to Escom (Wilson, 2010: 1). On the international level the way in which BP managed the biggest maritime oil spill in history (an estimated 4,9 million barrels in the Gulf of Mexico) also are a great cause for concern (Anon, 2010: 1; AFP, 2010: 14; Swint and Gismatullin, 2010: 17).

These type of transgressions are also aggravated by the extent of organisational pressure on managers to perform on various indicators, which also leads to compromises on organisational standards of ethical behaviour in order to achieve business objectives. According to Painter-Morland (2007) the most common pressures are meeting: financial or business objectives $(50 \%)$; schedule pressures $(38 \%)$; to help the organisation survive (30\%); to do as one's colleagues do and to resist competitive threats; the need to save jobs; career interests and peer pressure. The consequent widening of the moral gap make issues of ethics and morality not "soft issues" to management anymore.

\section{Objective}

The need exists for a comprehensive re-thinking on management behaviour in the contemporary neoliberal globalised market place (Lalor, 2009: 2; Van der Merwe, 2007: 1). A number of ethical studies have been done in connection with variables such as age; qualifications, working experience, gender; cultural effects and the correlation between religious conviction and ethics (Preble and Reichel, 1988; Hajjawi, 2008). Various legislation exist to promote the ethical behaviour of managers, but their attitudes towards ethical behaviour are not well understood (Hajjawi, 2008). In the current competitive markets, the context of ethical attitudes is central to understanding the moral framework within which managers personally interact in various capacities.
The objective is therefore to measure the ethical attitudes of managers on a micro-level along a number of stated scenarios and to determine if any underlying constructs exist in the ethical scenarios.

\section{MANAGERIAL BEHAVIOUR}

Defining management as the process of deciding the best way to use an organization's resources to produce (Rue and Byars, 2007: 2) is simple, but the actual job of managing is complex. The varied work roles of managers is difficult to master, yet vital to organizational success. Most management roles can be classififed as interpersonal, information-related and decision-making roles (Rue and Byars, 2007: 6). Within especially the context of decision-making, these roles have important consequences for both the manager and the company involved that also defines the ethical capital as a mainstream assessment of management's worth.

Underlying business ethics on the micro-level are philosophies that exist with sets of premises (Preble and Reichel, 1988). According to Painter-Morland (2010) and Robin and Reidenbach (1987: 44-58) the preferred methodology here is to expose managers to a variety of ethical approaches that can assist them in developing their decision-making model. Although Naude (2008) remarked that the reasons for the obvious moral decay can be found in as many models such as Kohlberg' lack of moral development and plain lawlessness in the transitional phase of transformation with values confusion as a consequence, no all inclusive model exist.

Although many approaches exist in the manner that decision-making is seen as a consequence of an individual's level of moral development, the Kohlberg's development model (Cherry, 2010) is utilized here in connection with moral decision-making skills. According to the Kohlberg model 5 phases of moral decision-making (reasoning from the lowest level of moral development to phase 5 as the highest) can be distinguished. Every phase faces its own challenges (risks), pertaining to unethical behaviour (Duska and Whelen, 2010). Briefly, the movement through the stages can be described as $\mathrm{L}$ :

a) Phase 1 - A concern for obedience and punishment. The problem here is that persons fear legal penalties, but find loopholes.

b) Phase 2 - A concern for co-operation with others for the benefit of self-interest and reciprocity.

The problems here relate to the fact that since bargains are struck in self-interest, a person tends to sell to the highest bidder.

c) Phase 3 - A concern for enduring personal relationships. Typical problems here are conflicts of interest and risks of nepotism. 
d) Phase 4-A concern for law and duty. The problem of no discretion that can be allowed which leads to inefficiency because of reliance on systems and red-tape.

e) Phase 5 - Principled reasoning. Hypothetical reasoning tends to idealize and set too high ideals which leads to the problem that the principle cannot shed light on a specific situation. In this phase persons are less likely to be tempted into moral compromise and thus assuming to be more beyond moral temptation.

In this regard a more contemporary approach for market place interactions are the stakeholder theory where the company interacts with interest groups coupled with the principles of corporate legitimacy and the stakeholder fiduciary principle. The main relationships found in agency-stakeholder theory (Bucar and Hisrich, 2001: 6567) all relate to managerial attitudes to ethics. Stockholders for example, will hold their stock even in cases of unethical managerial behaviour as long as the shares that they own meets certain investment criteria. In line with the theory of property (where someone behaves more ethical in dealing with their own property - the ethics of responsibility), managers can be incentivized to behave more ethical (Bucar and Hisrich, 2001: 78). The challenge are to create incentives in the shape of some type of managerial ownership like profit-sharing schemes, the property of the company should reflect philanthropic acts.

To champion ethical behaviour by managers, Jones et al. (1988: 166) and Painter-Morland (2007: 1) suggested that:

1. The way that stakeholders will be affected by managerial decisions should be analysed to ensure that managers can defend them to those affected by their actions.

2. Develop ethical control systems such as codes of ethics and regular sensitizing of the issues through training programmes. Encourage the various functional groupings to develop guidelines that will assist them on how to behave when confronted by these types of business scenarios.

3. Ensure that all managers are responsible for helping subordinates learning how to determine whether an action is unethical.

4. Ensure managers act as role models in this regard employees naturally look to those in authority to provide leadership and whose behaviour is scrutinized by their subordinates.

The complexity of these approaches to ethics is that it is embedded on the micro-level as it still is up to the individual to decide which approach makes the most sense in a situation. The basic belief is the tendency to believe that business decisions involve a realistic economic attitude and not a moral philosophy (Preble and Reichel, 1988). Some ethical decision-making tools combine these approaches by taking different angles on a moral dilemma. One such a tool is the so-called scenario setting which are empirically explored in this article. Managerial ethics as such is mentally demanding to integrate personal, philosophical and business issues (Hajjawi, 2008). The focus here is therefore also on the attitudes towards business scenarios that reflect the subjective assessment by an individual manager with respect to sets of premises which make up various business philosophies.

\section{EMPIRICAL INVESTIGATION}

The research data were collected by employing the tested ethics questionnaire by Abratt et al. (1992) and $\mathrm{Nel}$ et al. (1989) to measure the attitudes pertaining to ethical attitudes of managers. The questionnaire consists of 15 business scenarios (Table 1) which are still relevant for the contemporary manager. Considering the low reponse rates for ethics surveys, the sample appears to be a good representation. The respondents' recorded their ethical predisposition towards each scenario on a 4-point Lickert scale where a score of 1 represents "definitely wrong" and a score of 4 represents "not wrong at all". As a result, a low score on a postulated situation represents a higher ethical standard. The criteria appear in Table 1.

The analysis first calculated the mean values and standard deviations of each of the scenarios. Then the Cronbach alpha as measure for reliability and internal stability, as well as the KaiserMeyer-Olkin (K-M-O) measure of sampling adequacy were calculated (Du Plessis, 2009; Field, 2007: 667; Haasbroek, 2007: 5; Ellis and Steyn, 2003).

Data collection during 2009 was implemented by administering the survey to a sample of managers with at least two years managerial experience. The sample was drawn from middle and top level managers who are employed in the geographical diverse regions of the North-West, Vaal Triangle and Gauteng in South Africa. A total of 259 respondents completed the questionnaires. As these managers were requested in a personal capacity to participate, a commendable response rate of more than $95 \%$ were achieved. The statistical analysis revealed a very satisfactory Cronbach alpha coefficient of 0.788 (Field, 2007: 668; Anon, 2008). The K-M-O analysis also showed that it is statistically sound to subject the data to a factor analysis (Cooper and Schindler, 2003: $635)$ because a value of 0.773 was returned. The factor analysis extracted six factors. These factors all have Eigen-values greater than 1 and explains a favourable cummulative variance of $64 \%$.

\section{RESULTS}

The number of the scenarios in Table 1 corresponds to reference made to specific scenarios in the tables that follow. Table 2 shows the mean, standard deviations and alpha-values of the scenarios. In addition, all 15 of the scenarios show satisfactory alpha-values $(\alpha=>0.70)$.

Figure 1 shows the mean values of the attitudes of managers with regard to the scenarios (the lower the score the higher ethical attitudes). Scenarios 3 (lunch), 5 (whiskey), 6 (rugby), 8 (shares), 9 (weekend) and 12 (overseas trip) all show attitudes leaning towards the acceptability of these scenarios. The whiskey scenario is regarded to be particularly acceptable.

The factor analysis identified six factors. The minimum factor loadings were set at 0.45 (Field, 2007: 632). 
Table 1. Business scenarios.

1. A purchasing manager is offered the sum of R5 000 on condition that he awards a large contract to a certain company. He accepts the offer.

2. A project engineer awards a sizable tender. A week later the company invites him on an all expenses-paid shooting trip to their private game reserve. He accepts their offer.

3. Members of a company negotiating team accept a potential supplier's invitation to lunch.

4. On condition that he let them know of rival tender prices, a tender official is offered the opportunity of having his home carpeted throughout. He supplies every price tendered.

5. A company official receives a bottle of whisky form a supplier as a Christmas gift. He phones to say thanks.

6. Shortly after awarding a large contract, a company official and his son are invited to join suppliers at their private box at a major rugby match. They accept the offer.

7. Shortly before the announcement of a large new tender, one of the tender officials has half an ox and a case of whisky delivered to his home by one of the parties. He accepts the gifts.

8. A geologist working for a mining group gains important information regarding the development of a new reef. He immediately buys 1000 company shares.

9. A branch manager receives a voucher for a weekend's stay at a holiday resort from a supplier, as a birthday present. His secretary telephones his thanks.

10. A senior manager siphons petrol from his company car and transfers it to his wife's car for her shopping.

11. The marketing manager and his wife entertain friends at a top restaurant. He books the bill to his expense account dined with potential customers.

12. A company is known to be in the market for 20 heavy vehicles. One of the potential suppliers invites the specification engineer on an overseas trip so that he can "visit their highly sophisticated manufacturing facilities". He accepts the offer.

13. The financial manager knows that the next company report will be best yet. He instructs his broker to purchase R10 000 worth of shares on his behalf.

14. On returning from a visit to a supplier a buyer finds his boot filled with groceries. He does nothing about this.

15. On arrival at his hotel in another city, a company purchasing manager receives a phone call from the secretary of the sales manager. Her boss, she says, has instructed her to take him out for a "night on the town". He accepts her invitation.

Tables 3 and 4 shows the results of the factor analysis. Table 3 shows Eigen-values, variance and cummulative variance explained by the six factors, while the factor loadings (correlation coefficients) appear in Table 4.

Addional analysis according to Kaizer's criteria shows that factors that have an Eigen-value in excess of 1 , should be extracted and that the point where the variance explained from one factor to another starts to become marginal, are called the Point of Inflection (Field, 2007: 633). In this analysis the point of inflection is after Factor 1 , indicating that this factor represents the sole core factor in the analysis. The variance explained by the factors as well as the Eigen-values are shown in Figure
2. The factor analysis identified six factors which are identified as the following categories:

\section{Factor 1: Indirect grey ethical areas (behaviour)}

A total of six scenarios loads onto factor 1 . The scenarios are 2 (hunting trip), 3 (lunch), 5 (bottle whiskey), 6 (rugby), 9 (weekend) and 15 (night on the town). The majority of these scenarios depicts a situation where a gift or an invitation is involved after a deal has been struck. Most of these scenarios deal with either entertainment or minor financial rewards, and the fact that an 
Table 2. Cronbach alpha, mean and standard deviation values.

\begin{tabular}{cccccc}
\hline \multicolumn{5}{c}{ Valid N:246 Cronbach alpha: $\mathbf{0 . 7 8 7 9 8 5}$ Standardized alpha: $\mathbf{0 . 7 7 1 1 6 6}$} \\
\hline \multicolumn{7}{c}{ Means } & Var. if - deleted & Standard Deviation & Itm-Totl - Correl. & Alpha if - deleted \\
\hline q1 & 1.052846 & 43.83431 & 0.301784 & 0.174488 & 0.789142 \\
q2 & 1.861789 & 36.43083 & 1.036676 & 0.570084 & 0.759618 \\
q3 & 2.178862 & 36.64221 & 1.099406 & 0.510042 & 0.765371 \\
q4 & 1.121951 & 43.64347 & 0.487984 & 0.115043 & 0.791498 \\
q5 & 2.914634 & 36.82148 & 1.063700 & 0.517934 & 0.764638 \\
q6 & 2.308943 & 35.79271 & 1.073846 & 0.598906 & 0.756312 \\
q7 & 1.126016 & 42.49899 & 0.447640 & 0.330033 & 0.782859 \\
q8 & 2.028455 & 37.16863 & 1.137130 & 0.445501 & 0.772218 \\
q9 & 2.154472 & 36.40545 & 1.103113 & 0.527190 & 0.763585 \\
q10 & 1.024390 & 44.14971 & 0.200547 & 0.162086 & 0.789963 \\
q11 & 1.325203 & 42.33862 & 0.813116 & 0.153765 & 0.793418 \\
q12 & 2.288618 & 37.13195 & 1.129400 & 0.452712 & 0.771411 \\
q13 & 1.638211 & 38.35602 & 0.978964 & 0.438829 & 0.772292 \\
q14 & 1.268293 & 41.49474 & 0.658671 & 0.318121 & 0.781777 \\
q15 & 1.560976 & 39.16637 & 0.935873 & 0.391971 & 0.776335 \\
\hline
\end{tabular}

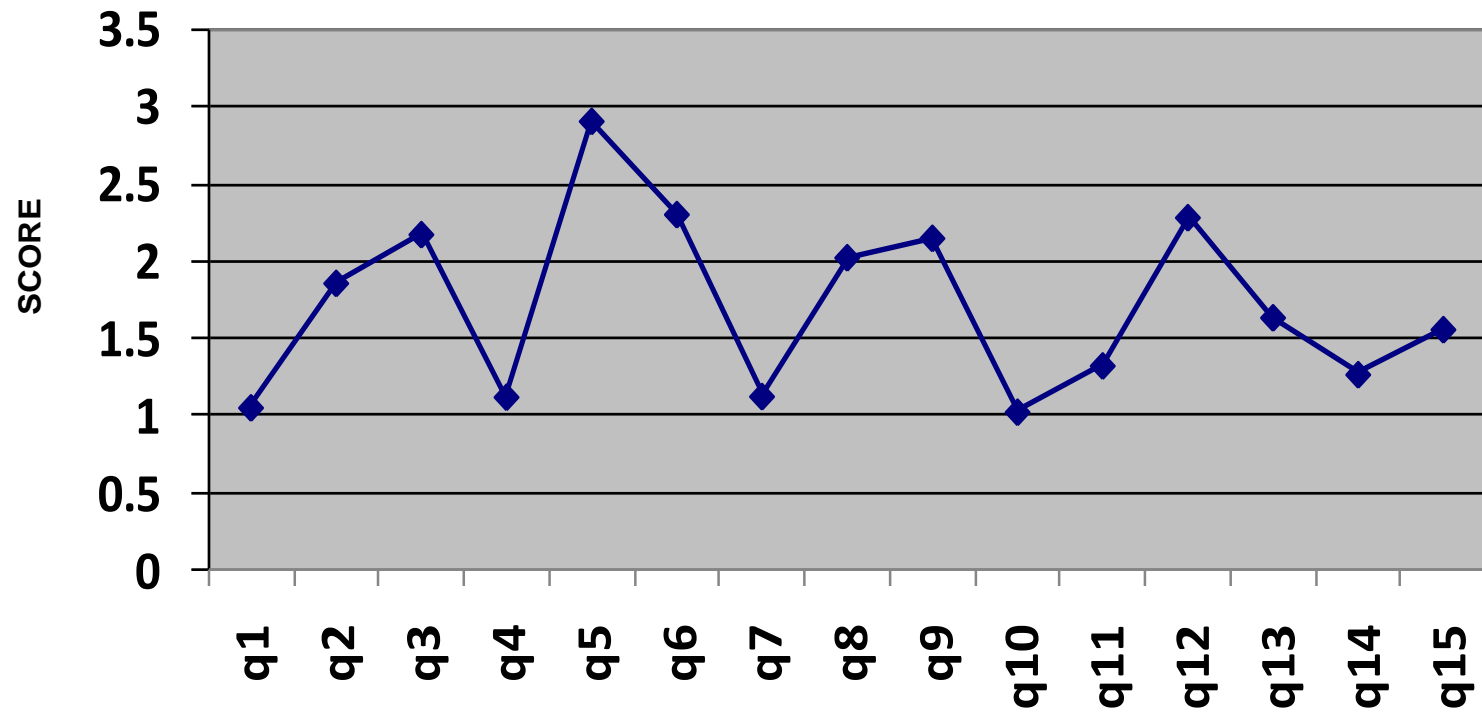

Figure 1. Mean values.

Table 3. Eigen-values, variance and cummulative variance.

\begin{tabular}{ccccc}
\hline \multicolumn{4}{c}{ Eigenvalues extraction: Principal components } \\
\hline S/N & Eigenvalue & Total - variance (\%) & cumulative - eigenvalue & Cumulative - (\%) \\
\hline 1 & 3.913158 & 26.08772 & 3.913158 & 26.08772 \\
2 & 1.482545 & 9.88363 & 5.395703 & 35.97135 \\
3 & 1.220434 & 8.13623 & 6.616137 & 44.10758 \\
4 & 1.067875 & 7.11917 & 7.684011 & 51.22674 \\
5 & 1.044966 & 6.96644 & 8.728978 & 58.19318 \\
6 & 1.007383 & 6.71589 & 9.736361 & 64.90907 \\
\hline
\end{tabular}


TABLE 4: FACTOR MATRIX

\begin{tabular}{|c|c|c|c|c|c|c|}
\hline \multicolumn{7}{|c|}{ Factor Loadings (Varimax normalized) Extraction: Principal components (Marked loadings are $>.40$ ) } \\
\hline & Factor - 1 & Factor - 2 & Factor - 3 & Factor - 4 & Factor - 5 & Factor -6 \\
\hline $\mathrm{q} 1$ & 0.092805 & 0.123148 & 0.053892 & -0.007200 & 0.062133 & 0.883685 \\
\hline q2 & 0.558137 & 0.139001 & 0.302716 & 0.362934 & -0.032291 & 0.261124 \\
\hline q3 & 0.653062 & 0.086333 & -0.008729 & 0.129439 & 0.222675 & 0.157231 \\
\hline $\mathrm{q} 4$ & 0.044318 & 0.034861 & 0.007087 & 0.941116 & 0.034716 & -0.025535 \\
\hline q5 & 0.776804 & -0.008086 & 0.111461 & -0.118377 & -0.088489 & 0.018682 \\
\hline q6 & 0.755072 & 0.143911 & 0.144339 & 0.035723 & -0.054281 & 0.143926 \\
\hline q7 & 0.103516 & 0.792595 & 0.162183 & 0.128140 & 0.006377 & 0.199580 \\
\hline q8 & 0.224511 & 0.050148 & 0.784206 & 0.112265 & 0.068631 & -0.122418 \\
\hline q9 & 0.619292 & 0.201241 & 0.227986 & 0.038433 & -0.031910 & -0.093675 \\
\hline q10 & 0.107884 & 0.681644 & -0.245233 & 0.027875 & 0.124713 & 0.103375 \\
\hline q11 & -0.088386 & 0.156629 & 0.108086 & 0.089543 & 0.833475 & 0.043244 \\
\hline$q 12$ & 0.521061 & -0.052093 & 0.103097 & -0.138769 & 0.583733 & -0.002047 \\
\hline$q 13$ & 0.200511 & 0.016944 & 0.764246 & -0.067632 & 0.126774 & 0.207316 \\
\hline q14 & 0.123405 & 0.619470 & 0.373762 & -0.140679 & 0.048947 & -0.268879 \\
\hline q15 & 0.525974 & 0.008034 & 0.123462 & 0.043587 & 0.204681 & -0.296470 \\
\hline
\end{tabular}

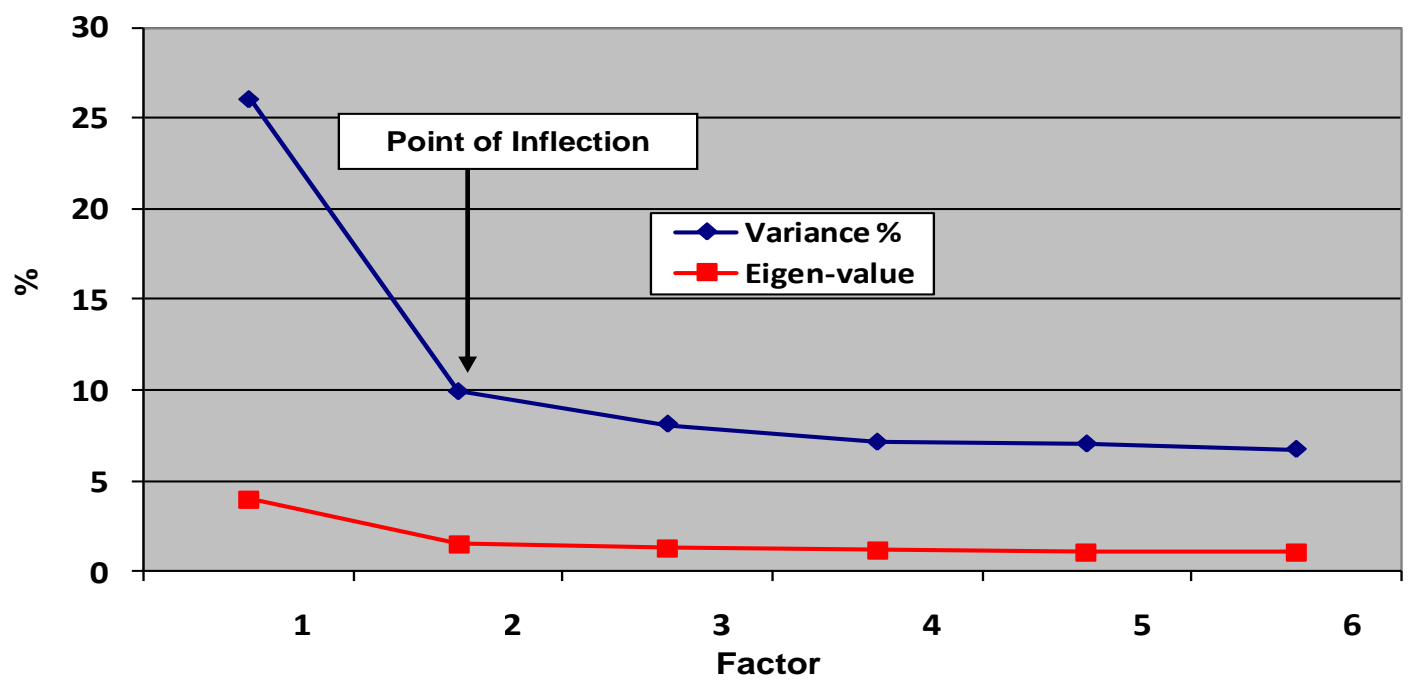

Figure 2. Variance explained by the factors.

invitation is prevalent shows that the role of choice and transparency also plays a role in the acceptability of the scenarios. Most of the scenarios are debatable and do not portray a situation that is clearly unethical or even illegal. It does not involve stealth and cunningness on the part of the respondent either. The factor is thus labelled as "indirect grey ethical areas". This factor is the core factor of the analysis and explains a variance of $26 \%$.

\section{Factor 2: Direct unethical behaviour}

Factor 2 focus strongly on direct unethical, devious and even illegal behaviour. Three scenarios loads onto the factor: 7 (whiskey before the deal-bribe), 10 (siphons petrol) and 14 (boot full of groceries). All of these actions are clearly unethical. In addition the monetary value of the "gifts" are substantial. The factor explains almost $10 \%$ of the variance.

\section{Factor 3: Insider trading}

Both scenarios that resorts under factor 3 deals with using inside information for personal gain. Scenario 8 (geologist buying shares) and scenario 13 (financial manager buys shares before financial report) clearly depicts a situation where employees uses their insider 
knowledge to gain personal wealth. The factor explains $8 \%$ of the variance.

\section{Factor 4: Leaking competitive information}

This factor is labelled as leaking competitive information and although only one scenario (4) loads strongly here, the factor can not be dismissed due to the fact that it passed the Kaiser-test and has an Eigen-value that is larger than 1 (Field, 2007: 633).

\section{Factor 5: Integrity and trust}

The fifth factor (declaring a variance of $7 \%$ ) deals with integrity and trust. Two scenarios which are clearly not trustworthy behaviour loaded to the factor, namely 11 (charging a family dinner to the company account) and 12 (overseas trip). In both cases the employees is placed in a position of trust and integrity and must act accordingly.

\section{Factor 6: Bribes}

Similar to Factor 4, only one scenario (1) strongly loads to the final factor. The scenario deals directly with bribing and it explains $6.7 \%$ of the total variance.

\section{DISCUSSION}

The research focused on respondents to comment more on behavioural statements and less philosophical in nature. The importance of this kind of scenario testing over time is due to the fact that the behaviour of peers is also one of the best predictors of the ethical conduct of others (Painter-Morland, 2010). Therefore the development of ethical decision-making (reasoning) skills amongst managers is important as it also creates capacity for future mentoring. The empirical findings reiterate the importance of the mentioned Phase 5 moral development by managers which requires strong principled reasoning skills.

This is also aggravated by the seemingly disregard in this country to hold individuals and organisations accountable for their behaviour. It illustrates an obvious lack of considering the normative implications of managerial actions. Therefore, the South African situation requires another dimension - that (Gilligan, 2010) which operates according to an ethics of responsibility and care. Steyn (2010: 4) confirmed this by remarking that people are far too attached to their personal loyalties to make this country work for the benefit of all.

The research confirms that ethical grey areas indicate the core factor of the analysis and explains a dominant variance of $26 \%$. This grey areas indicate ethical dilemmas where the borderline between right and wrong actually is blurred. This grey area borderline tends to change depending on the personal point of view and on the current conditions prevailing (Mirchandani, 2011). Clearly, it is time for more pragmatic thought about ethical grey areas.

These problems relating to managerial ethics persist despite an increase in regulation. The problem worldwide is that the regulatory regimes are not capable of remedying what are largely ethical problems. Failure occurs when those responsible for management either fail to see what a real ethical issue is. At all levels of those with managerial responsibility, there is simply no escape for the responsibility for exercising good judgement, for which people are then held accountable. Responsible management, starting at the top, need to show leadership. They need to assume control of the organizational culture ("the language"), starting with a review of their personal ethical standards. Only by instilling corporate values that clearly authorize and encourage ethical behaviour and just as clearly discourage unethical performance can headway be made at remedying an environment ripe for corporate failure (Cohen, 2002).

An organization therefore have to clearly communicate its position on ethics and the related responsibilities to all by making ethical values and norms a central part of its culture. Research by the World Economic Forum (2010: 3 ) in which more than 130000 respondents were covered concluded a "near universal call for values to underpin the economic systems". The poll found that education and family lead as sources of personal and professional values, but South African respondents indicated that religion and faith are the most likely drivers instead. Professional experience were a significant driver of values for only $11 \%$ of all repondents. Although $51 \%$ of respondents indicated that honesty, integrity and transparency should be the values that are most important, the vast majority $(60 \%+)$ believed that people do not apply the same values in their private and professional lives (Nejati et al., 2010; WEF, 2010: 4).

The fact that the repondents seemingly showed high moral standards on the concrete-behavioural level is positive. The factor analysis reiterate the multitasking challenges for managers per sé, which ultimately culminate in problems at the work place relating to their work. The various role interests that can be derived from a managerial position illustrate their dilemma of balancing a number of roles and as such, the complicated nature of the ethical challenges for managers. Van Wart (1996: 525-533) identified 5 competing "role interests" in this regard:

1. The public interest - it is expected from business to serve the common good of the public.

2. The legal interest - all stakeholders have interests in at least striving to a situation wherein the values of the 
constitution are upheld.

3. Personal interests - management and its subordinates need also to look at the wellness imperative of family and friends.

4. Organizational interests - at the same time that an organization is serving the public good, it also need to protects its own interests.

5. Professional interest - compliance relating to different codes of conduct and ethics.

Childs (1995) found a lot of reluctance in the business environment to apply religious values in their business activities, because of the continuous dualistic assumption that spirituality and business must be seperated. The persisting problem and the solutions to the problem lies seemingly in the concept of attitude. Ethical attitudes are the consequence of personal values, experiences and the environment in which one functions (Donaldson and Dunfee, 1999; Tveit, 2010: 49).

Ethical attitudes may be influenced by different social institutions. Institutional incentives may also alter the reactions of managers to the challenges being faced by the set of business scenarios. Based on the stakeholder theory, it follows that managers that are exposed to larger relative ownership responsibilities, will exhibit higher ethical attitudes than otherwise. Thomson (1999: 2) concluded that it is of no coincidence that the most stringent ethical businesses tend to be managed by individuals who are willing to accept a lower profit if necessary to follow their personal beliefs, but once extrenal shareholders are involved, a more single-minded focus on profit follows. A set of environmental factors also influence ethical attitudes (Bucar and Hisrich, 2001: 61):

1. Norms and pressures from community and peers as internalized factors. Fear of punishment was found to be the least influencable.

2. In terms of externalized factors, competition received the highest rating on the influence scales

3. Respondents perceived their own ethical standards higher than others, which basically confirms the "halo effect".

The focus should be away from rigid control mechanisms, but more on the understanding of ethical values in an empowered environment. Empowering people make the necessity of belief systems an integral part of ensuring compliance "plus". The ethics dimension needs to be managed in a more explicit way just like the other functional areas like finance, human resources, stocks; assets and marketing (Van der Merwe, 2007: 3).

Prescriptive ethics in the form of universal ethical principles that define best practice should clearly guide every business manager (Motlanthe, 2010: 11). But what is currently experienced is a type of "self-seeking leadership" that places individual interests above anything, while the demand for a type of "servant leadership' role for management in South Africa is a primary requirement for addressing the increasing unethical behaviour. Lalor (2009: 2) indicated that aspects of the Transformational and Servant approaches to managing and leadership have a moral dimension - something which seems to be the "missing link" in the South African context. It was Benjamin Franklin that reminded us: "it takes many good deeds to build a good reputation, and only one bad one to lose it..." (Ancona et al., 2007: 106).

\section{Conclusion}

The results of the empirical investigation indicate that over the long run no significant strides were made regarding guidance to managers on how to deal with the ethical dilemmas that stems from the ethical grey areas of decision making, codes and other guidelines in the work place. It confirms that the majority of managers are still challenged by these grey areas and it can be deduced that there seems to be an underestimation of these ethical dilemmas. Further research is needed on the factors that influence the ethicall decision making standards.

What is needed is a manager with a conscience to address these challenges. The welfare for the common good will have to be better insured by a sense of higher purpose than purely own material gain. A more aggregated coordinated effort as well as the "right kind" of leadership is necessary to contribute to the moral regeneration of society. The drive should be to change the attitudes of managers, which are in itself a much more challenging endeavour that many are prepared to admit.

\section{REFERENCES}

Abratt R, Nel D, Higgs N (1992). An Examination of the Ethical Beliefs of Managers using selected Scenarios in a Cross-Cultural Environment. J. Bus. Ethics 11:29-35.

Associated Foreign Press (AFP) (2010). Enorme getal eise verswelg BP, tap koffers. Rapport: 14 Julie. 4.

Ancona D, Eccles RG, Newquist SC, Shatz R (2007). Reputation and Its Risks. Harvard Bus. Rev. pp. 104-114. February.

Anonomous (2008). Types of reliability. Research methods knowledge base. [Web:] http://www.socialresearchmethods.net/kb/reltypes.php [Date of Access: 03/03/2009].

Anonomous (2010). Gulf of Mexico oil spill coming to an end. Business Day: 1. August. 5

Bucar B, Hisrich RD (2001). Ethics of Business Managers vs. Entrepreneurs. J. Dev. Entrep. 6(1):58-83.

Camerer L (1996). White-collar Crime in South Africa: A comparative perspective. [Web:] http://www.iss.org.za/Pubs/ASR/5No2/WhiteCollarcrime.html. [Date of access: $31 / 05 / 2001]$

Cherry K (2010). Kohlberg's Theory of Moral Development: Stages of Moral Development.[Web:].http://psychology.about.com/od/developm entalpsychology/a/kohlberg.htm. [Date of access: 8 October 2010].

Childs JM (1995). Ethics in business: Faith at work. Relations among and between career values and Christian religious values. Counseling and Values. The Center for Ethics and Corporate Policy. [Web:].

http://www.google.co.za/search?hl=en\&q=CHILDS+AND+1995+AND + religious +values\&btnG $=$ Search\&meta $=\& a q=f \& a q i=\& a q l=\& o q=\& g s \_r$ 
fai. [Date of Access: 08/10/2010].

Cohen S (2002). Good corporate ethics needs grey-area leadership, not black-and-white rules. http://www.onlineopinion.com.au/view.asp?article=518\&page=2. [Date of Access: 31/01/2011].

Donaldson T, DUNFEE, TW (1999). Ties that bind - a social contacts approach to Business Ethics. Boston: Harvard Business School Press.

DU Plessis JL (2009). Verbal coomunication with the author. Statistiese Konsultasiedienste. Potchefstroom:NWU.

Duska R, Whelen M (1975). Moral Development: A Guide to Piaget and Kohlberg (New York: $\quad$ Paulist). http://www.vtaide.com/blessing/Kohlberg.htm. [Date of Access: 8 October 2010].

Ellis SM, Steyn HS (2003). Practical significance (effect sizes) versus or in combination with statistical significance (p-values). Manag. Dyn. 12(4):51-53.

Eybers J (2010). Kragbase vat 83\%. Rapport: 1. Julie, 4.

Gilligan C (2010). Feminist Ethics An Alternative Voice. [Web:] http://www83.homepage.villanova.edu/richard.jacobs/MPA\%208300/t heories/feminist.html. [Date of Access: 08/10/2010].

Field A (2007). Discovering statistics using SPSS. $2^{\text {de }}$ uitgawe. London: Sage Publications.

Haasbroek A (2007). Brand positioning in the remarket automotive industry. MBA Dissertation. North-West University: Potchefstroom.

Hajjawi O (2008). Pioneering in Teaching Business Ethics: The Case of Management Accounting in Universities in Palestine. European J. Econ. Finance Administr. Sci. $14 . \quad$ [Web:] http://www.eurojournals.com. [Date of Access: 14/08/2010.] Institute of Business Ethics (IBE) (2010). Institute of Business Ethics Reports and Survey Findings. [Web:]. http://www.ibe.org.uk/findoutmore/3surveys.html. [Date of Access: 21/08/2010].

Jones GR, George JM, Hill CWL (1988). Contemporary Management. McGraw-Hill:USA.

Lalor C (2009). Ethical Leadership in the Context of Globalization. (Paper presented at the annual Ben-Africa conference, Accra Ghana). 3-5 $5^{\text {th }}$ August.

Lauer M (2009). The importance of critical social theory in the African business paradigm. (Paper presented at the annual Ben-Africa conference, Accra Ghana). 3-5 $5^{\text {th }}$ August.

Mirchandani A (2010). Things in grey are. [Web]:
[W http://www.articleclick.com/Article/Things-in-grey-area/1192543. [Date of Access: 09/01/2011].

Motlanthe K (2010). Business ethics should be at the forefront. Business Day: 11. August. 5.

Naude P (piet.naude@nmmu.ac.za) (2008). Discussion of philosophic model. [E-mail to:] Lotriet, R.A. (ronnie.lotriet@nwu.ac.za). August.25.
Nejati M, Jamali R, Nejati M (2010). Students' Behaviour in Iran. J. Bus. $\begin{array}{llll}\text { Ethics } & 7(4): 277-285 . & \text { April. } & \text { 30. }\end{array}$ http://www.springerlink.com/content/4mt2ng3615h006w8/. [Date of Access: 8 October 2010].

Nel D, Pitt L, Watson R (1989). Business Ethics: Defining the Twilight Zone. J. Bus. Ethics. 8:781-791. [Web:]. http://portal.acm.org/citation.cfm?id=158015. [Date of Access: 08/10/2010].

Painter-Morland MJ (2007). Dealing with moral values in pluralistic working environments, $\mathrm{PhD}$ thesis, University of Pretoria, Pretoria, viewed yymmdd. [Web:] http://upetd.up.ac.za/thesis/available/etd03232006-145332/H298/th. [Date of access: 8 October 2010].

Painter-Morland MJ (2010). Questioning corporate codes of ethics. Business Ethics: A Europ. Rev.19(3):265-279. July. [Web:]. http://onlinelibrary.wiley.com/doi/10.1111/j.1467-

8608.2010.01591.x/full. [Date of access: $8 / 10 / 2010]$.

Preble JF, Reichel A (1988). Attitudes towards business ethics of future managers in the US and Israel. J. Bus. Ethics 7:941-949.

Robin DP, Reidenbach ER (1987). Social responsibility, ethics and marketing strategy - closing the gap between concept and application. J. Mark. 51:44-58.

Rue LW, Byars LL (2007). Management Skills and Application. McGraw-Hill: Boston.

Shankar SSR (2010). Values: Elusive Reality. (In: Values for the PostCrisis Economy: 47-48. The World Economic Forum. Geneva. Switzerland).

Steinacker J (2010). Sucesses and failures in the courts. Sunday Times. 13. June. 27.

Steyn JG (2010). Bureaucadres" only hold back country's growth Sunday Times: 4. June. 27.

Swint B, Gismattullin E (2010). BP Investors angry about executive pay. Business Day: 17. April. 16.

Thomson R (1999). Ethical Businesses. Helicon: London.

Tveit OF (2010). Attitudes Before, During and After the Crisis. (In: Values for the Post-Crisis Economy: 49. The World Economic Forum. Geneva. Switzerland).

Van Der Merwe S (2007). Strengthening the moral fabric in the SA workplace. Unpublished draft.

Van Wart M (1996). The sources of ethical decision-making for individuals in the Public Sector. Public Administr. Rev. 56(6):525-533.

Wilson J (2010). ANC admits part racked by bribery, vote buying. Business Day: 1. August. 5.

World Economic Forum (WEF) (2010). Values for the Post-Crisis Economy. The World Economic Forum. Geneva. Switzerland. 